\title{
Good Intentions, Debatable Results: Catholic Missionaries and Indian Schooling in Hobbema, 1891-1914
}

Gary Taljit

ABSTRACT: Oblate missionaries played a large role in educating and "civilizing" natives in the Canadian Northwest in the late nineteenth and early twentieth centuries. The missionaries' goals were to gain converts and to prepare the Indians to cope with the new, white-dominated sociery. Under the aegis of a Dominion government that sought an inexpensive means of assimilating the Indians, the missionaries built schools where narive children could be inculcated with "Canadian" values and mores. This essay looks at missionary education at the Hobbema residential school from 1891 to 1914 as a case study. The writer argues that, for a variety of reasons, Indians often resisted the educational efforts of the Oblates and the sisters who taught at the school. Indians questioned the motives of the missionaries, the health conditions at the schools, and the benefits of the education. However, some Indians believed education could help them adjust to the new society. Nevertheless, the ethnocentrism, paternal ism, and strict discipline that characterized the residential school experience often made it an unhappy one for children, although the situation for students: at Hobbema was probably nor as bad as it was for Indian students ar other localities.

Missionaries played a significant role in the education of natives in the Canadian Northwest in the late nineteenth and early twentieth centuries. Particularly prominent were priests from the Catholic order known as the Oblates of Mary Immaculate. Itinerant priests roamed with the Metis and Indians on their buffalo hunts, attempting to teach the catechism and to spread the faith. As more permanent missions were established over the years, schools became an integral part of the evangelization effort. The missionaries' goals were to gain converts and to prepare the prairie Indians for the advancing tide of white setdement by "civilizing" them. For the missionaries, and white society in general, the civilized Indian was one who was literate in French or English, dressed in non-Indian clothes, lived in a house resembling that of whites, supported his family by farming where that vocation was possible, and was a Christian. The education of children became the most effective means to convert and civilize the Indians. The cashstrapped Dominion government, which sought to assimilate the Indians peacefully and inexpensively, realized that its policy could be achieved with help from the missionary educators; thus, the government became willing to help fund mission-run schools. Although both 


\section{Past Imperfect}

the government and the missionaries saw the Indians as needing outside intervention to help them cope with the threats of starvation, disease and white settlement, the motives of both parties were more self-serving than altruistic. In their zeal to convert and assimilate the Indians, the missionaries employed extremely paternalistic measures that were not always welcomed by the recipients, who often resisted the missionaries' efforts.

This paper examines the motivations of the missionaries and the reaction of the Indians, using, as a case study, the Oblate boarding school at Hobbema in the period from about 1891 to 1914 . The paper will also examine the role of the government in missionary education. The time period of 1891-1914 chosen for this essay encompasses the initial growth and the consequent expansion and consolidation of the Hobbema boarding school. The time span also provides enough scope to examine missionary and government interaction and the response of Indian students to missionary education over a period of time. Although most of the documents used in this paper were written by the Oblates or by the Sisters of the Assumption who taught at the Hobbema school, the evidence shows that the Indian response to missionary education varied from resistance to indifference to sometimes-grudging acceptance. These findings are in line with other studies done on Oblate-run residential schools. ${ }^{1}$ The Cree Indians of Hobbema often distrusted the motives of the missionaries whose schools were funded according to the number of students in attendance. Indians also feared for their children's health in the residential schools which had a relatively high death rate. Furthermore, Indian parents did not like the teaching methods of the mission schools which included corporal punishment, half-days of labour and the denigration of Indian culture. However, some Indians did see a benefit to schooling, for in some cases it helped them better to understand and to cope in the white man's world.

It should be noted that in the present-day context, with this society's growing awareness of Native rights and with recent nation-wide revelations of abuse in schools run by religious groups, the topic of missionary education is an emotional and controversial one. There may be a tendency today to regard the missionaries as the "bad guys." But, while it is true that the missionaries did try to put an end to the Indians' traditional beliefs, many - though certainly not all - were also dedicated and committed people who genuinely wanted to help ease the transition of the Indians to the white man's world. Nevertheless, their desire to obtain Christian converts and pupils for their schools often took precedence over concern for the Indians, whose traditional way of life they regarded as un-Christian, uncivilized and unprogressive. For 
example, the records of the Sisters of the Assumption indicate that the sisters valued the conversion of Indians to Christianity more than they valued the lives of those very Indians. Such behaviour by the missionaries can only be described as selfish, if not reprehensible. Indeed, in July 1991, the Oblates apologized for the part they played "in the cultural, ethnic and religious imperialism that was part of the mentality with which the peoples of Europe first met the aboriginal peoples and which consistently has lurked behind the way the native peoples of Canada have been treated by civil governments and churches."

The treatment of native peoples by missionaries and government has been examined by many historians. There is a fairly large body of literature on prairie Indians and education, much of it written relatively recently. Critics have tended to be scornful of the residential schools for their authoritarian discipline, their promulgation of European values and their insinuations of Indian inferiority. According to one interpretation put forth by the Indian writer Harold Cardinal in The Unjust Society: the Tragedy of Canada's Indians, the residential schools established by ninereenth-century missionaries in Western Canada attempted to destroy Indian language and culture through the oppression of young Indians. The descendants of those Indians who were fortunate enough to escape with their lives were now engaged in a struggle to revive their languages and culture, Cardinal wrote in $1969 .^{3}$ His argument arose in reaction to the Liberal government's White Paper which attempted to absolve the federal government of its responsibilities to Indians. Cardinal's work also coincided with the civil-rights movement of the 1960s, when oppressed social and ethnic groups in North America and elsewhere began pressing for justice and recognition.

Other interpretations, notably that of Jacqueline Gresko, emphasize that neither missionary educational efforts nor native responses were as simplistic as Cardinal makes them out to be. Rather, educational efforts and native responses varied according to the native culture, the particular school programs, and the nature of white settlement. Native students could and did resist or reject Catholic school programs, while "retaining and developing their own cultural institutions in the form of dancing groups and traditional gatherings." Some historians, like J.W. Grant, emphasize the good intentions of missionaries, while still being sympathetic to the Indian viewpoint. In The Moon of Wintertime, Grant notes that missionary education of Indians was underfunded, paternalistic, and without a clear goal. But despite the occasional horror stories about Indian education, Grant argues the missionaries tried their earnest best to help the prairie Indians overcome their desperate state. If the missionaries are to be faulted, it should not be for their efforts but for their misguided authoritarianism and one-way communication to 


\section{Past Imperfect}

which Indians could only respond with passive acquiescence. ${ }^{5}$ This paper's case study examination of the residential school at Hobbema tends to confirm the interpretations put forth by both Gresko and Grant.

Before further discussing missionary education in the Northwest and at Hobbema, some background information on the Oblates and on government policy might be useful. The Oblate order was founded in southern France at Aix-en-Provence in 1816 by Eugène de Mazenod, who wanted to spread Christianity throughout the world. The Oblates came into being after the restoration of the Bourbons, and like most other orders of the time, they were ultramontanists, professing fidelity to the papacy and opposition to liberalism. The first Oblates arrived in Canada in 1841, and in 1845 two of them reached the Red River settlement in what was then known as Rupert's Land. ${ }^{6}$ This marked the beginning of what was to become a widespread and enduring Oblate influence on missionary work in the Northwest. By 1852, there were eight Oblate priests in the region. Their concern with the salvation of Indians prompted them to travel far into the parkland to spread the word. On these itinerant missions, they strove to provide religious instruction to the natives, particularly the children. ${ }^{7}$ Teaching Indians to read and write and sing hymns was one method of converting them. Thus, as the Oblates established permanent missions, schools became an important part of their effort to Christianize the Indians. The mission schools were established in places that best suited the goals of proselytization. The three Rs - reading, writing and arithmetic were taught, but religious instruction in hymn singing and Scripture reading was most important. ${ }^{8}$

The Catholics had a policy of not allowing priests or ordained ministers to teach in Indian schools, as they were needed for pastoral duty among the Indians and the burgeoning white population, especially after 1880 . Hence, most Catholic schools were turned over to the Grey Nuns or to other orders of sisters. The sisters generally had no technical qualifications as teachers but were experienced from convent or seminary college training. However, although it was the sisters or hired laypeople who taught the classes, clerics remained deeply involved in the operation of the schools as principals and as spiritual leaders. The Oblate Père played a central role in the lives of those who surrounded him. To the students and more especially to the sisters, he was "a friend, a benefactor, a father, and God's interpreter."

After the Dominion government took control of Rupert's Land from the Hudson's Bay Company on December 1, 1869, it slowly began to concern itself with Indian education on the prairies. Along with the establishment of treaties and reservations, education also became a part 
of Indian policy. ${ }^{10}$ Indeed, all the treaties signed by the prairie Indians contained promises of education. For example, Treaty No. 6, an adhesion to which was signed in 1877 by the Cree Indians, many of whom later settled at Hobbema, stated: "And further, Her Majesty agrees to maintain schools for instruction in such reserves hereby made as to Her Government of the Dominion of Canada may seem advisable, whenever the Indians of the reserve shall desire it." The Indians were aware that their traditional way of life was vanishing, and it is apparent that they demanded education as part of the conditions of treaty, even if they did not realize exactly what they would be getting. Alexander Morris, the Lieutenant-Governor of Manitoba, the Northwest Territories, and Keewatin and the principal negotiator of many of the treaties, noted that the Indians of Treaty No. 6 were willing to learn farming and carpentry, and that they universally demanded teachers to help them adjust to a new way of life. ${ }^{12}$

The Conservative government, which returned to power in 1878 , seemed to accept the idea of sharing control of educarion with the missionaries. After all, the aims of both were similar: the Christianization and acculturation of the Indians. ${ }^{13}$ The missionaries wanted to save souls and the government wanted the prairies to be settled peacefully. The government, already in debt, had no intentions of frghting costly Indian wars such as those in the United States. As the major Christian denominations had all been involved in educational and missionary work with the Indians before Confederation, federal officials realized they could save money by building on the existing ecclesiastical institutions rather than developing a new educational system. In addition, they believed the dedication and moral suasion of the missionaries would contribute to the success of the plan. ${ }^{14}$ Both parties also had a definite humanitarian impulse, for the prairie Indians by the late 1870 s were in dire straits due to the ravages of disease, the encroachment of white settlement, and the loss of the buffalo which had provided their livelihood.

By educating Indians in the ways of white "civilization," the missionaries and the government hoped that the Indians would eventually be weaned from their "heathen" traditions and would become self-sufficient and assimilate to the norms of Canadian society. Indian education policy was meant "to protect Indians from the worst features of white society, to prepare them for the labour market, and to 'save' them for the sake of their souls."15 However, Indian culture was deemed irrelevant by church and government officials, who insisted that the Indians had to adopt the white man's values and conform to his ideals of industry, temperance and thrift. ${ }^{16}$ This viewpoint denied the fact that the prairie Indians, who lived a communal lifestyle, had long had their 


\section{Past Imperfect}

own ideals of industry, temperance and thrift. Indian children were taught values which emphasized respect for all living things, sharing, self-reliance, individual responsibility, and proper conduct. ${ }^{17}$ The conviction that the Indians had to be "Canadianized" was a paternalistic and ethnocentric one, but it had a long past. The Catholic religious orders that accompanied the first French settlers had also wanted to educate Indians according to the precepts and practices of their society, which they believed was culturally and technologically superior to the Indians'.$^{18}$ By the mid-nineteenth century, the ethnocentrism of Europeans became even greater due to the influence of Social Darwinism. The fact that Indians were no longer valuable as military and trading partners, and were occupying valuable agricultural lands also contributed to government policies of coercive assimilation. ${ }^{19}$

The policy of civilizing the Indian through education was ostensibly sanctioned by the Canadian government in a report completed in March, 1879 by Nicholas Flood Davin, who was sent by the government to investigate the system of Indian industrial schools in the United States. The Davin report contained some thirteen recommendations, but the two major ones were that monetary aid to denominational schools should continue, and that the government should build and finance no more than four industrial schools, which would be administered by the clergy of various denominations. Davin noted that a religious influence in education was necessary, for it helped Indians to conform to white society by taking away their "simple mythology." 20 The significance of the report was that it formalized and added emphasis to government policy which had, heretofore, been conducted on a haphazard and temporary basis.

The system of Indian education that thus emerged was financed largely by the federal government and managed by the missionaries, who were pleased at being able to build up their organizational structure with the aid of state subsidies. Both day and residential schools were built, but the latter were preferred by the government and missionaries because they removed children from a "retrogressive" home life, thereby accelerating the civilizing process and ensuring regular attendance. The residential schools were divided into two categories: boarding and industrial. Boarding schools were usually located on reserves and catered to students between the ages of eight and fourteen, approximately. Industrial schools were located off-reserve, close to areas of white settlement, and were for older students. In a sense, they functioned as a type of high school for those students who graduated from the boarding schools. Both types of schools aimed to give a basic education to their students, but boys were also trained to be farmers and 
mechanics, while the girls were trained to be housewives, who could clean, cook and sew. ${ }^{21}$

With the sanctioning of their work by the Davin report, missionaries became increasingly aggressive in seeking government aid. For the most part, during the 1870s, the Oblates in Western Canada had to fund their schools themselves, as the donations that used to come from France had dried up with the advent of the Franco-Prussian War in $1870 .{ }^{22}$ This lack of funds, which was a common problem over the years, would cause headaches for Oblate administrators like Rev. Vital Justin Grandin, who was the Bishop of St. Albert, the diocese in which the Hobbema mission was founded in 1881. But the willingness of the government to accept at least partial financial responsibility allowed for the rapid expansion of schools in the Northwest, although the missionaries continued to play a large role in funding.

In 1871, there were five schools in the diocese of St. Albert, but Grandin, fearing for the fate of the Indians, wanted to expand the missions and schools. In order to obtain the needed revenue, he worked tirelessly to raise funds from wealthy donors in Ontario and Quebec. These "begging missions" would later be extended to France and were important sources of money until $1914 .^{23}$ The motivations of Bishop Grandin are made clear in the letters and articles he wrote in an effort to raise funds. In a 17 January 1878 letter addressed to an unidentified "Madame," Grandin promoted the work of the schools of the Northwest and pleaded for funds to run the schools. ${ }^{24}$ Grandin said that missionaries had the duty to propagate the faith among Indians, especially the young, in order for them to be able to survive in a new society where the buffalo hunt was a thing of the past, and where starvation was a daily threat. To stop the destruction of the Indians, it was necessary to have money to build numerous and spacious "orphanages," not only for orphans, but for other children who would be sent there by their parents. Money was also necessary, in some cases, to buy farms, which would be connected to the orphanages. At these farms, children could grow up and learn to be farmers, housewives, and good citizens. This system would bring up children, who would no longer be "savages" 25 but would be able to live off their work in the new society. For Catholic missionaries like Grandin, civilization went hand in hand with a sedentary agricultural lifestyle. Where circumstances of climate and soil did not permit an agrarian way of life, missionaries were willing to accept the hunting, fishing, and gathering ways of their flock. Grandin thus saw the missionary role as one that included not only the salvation of souls, but the education of Indians in an effort to spare them from the perils of starvation and the vices of the white man's world. 
In the case of Hobbema, or the mission of Notre Dame des Sept Douleurs, located some 70 kilometres south of Edmonton, the first school was opened in 1887 in the priest's house. It began with an attendance of 12 students. ${ }^{26} \mathrm{~A}$ day school was established in 1891, but despite the midday meals offered by Madame Ursule Beauregard, who ran the school, attendance was poor and sporadic. ${ }^{27}$ Because of such difficulties, which were usually attributed to parental indifference, the Oblates preferred to have boarding schools or "pensionnats," where they could have greater control over their charges. Establishing a permanent presence by building a school and other missionary facilities was also one way for a religious denomination to stake a claim to a region. ${ }^{28}$

To these ends, Bishop Grandin decided to obtain a boarding school for Hobbema, and in 1894 he requested the assistance of the Sisters of the Assumption to run it. ${ }^{29}$ The order of the Sisters of the Assumption was founded in 1853 as a teaching order. Three sisters arrived in 1894 to teach at what became known as the Ermineskin boarding school. It was named for one of the bands on the reservation, on whose land it was built. ${ }^{30}$ Catholic boarding schools were usually started by the church, but, after a few years of operation, they would get government recognition and grants. Such was the case with the Ermineskin school.

After the first year of operation in 1894, there were 12 boarders, but no government funding. The following year, the school was able to expand to 20 students after the Department of Indian Affairs allocated to the school the usual subsidy of $\$ 72$ per student, $\$ 12$ of which was in cash, while the rest was in effects. The grant was recommended by local Indian agent D.L. Clink, whose responsibility included the inspection of such schools. ${ }^{31}$ Later on, there was much joy among the Oblates and the Sisters of the Assumption when the department granted $\$ 2,500$ towards the construction of a new school with room for 50 students. It also provided a sewing machine, desks, mattresses, chairs, and tables. The three-storey building, measuring 40 feet by 50 feet, opened in August 1897 with an enrolment of 30 students. However, the building ended up costing $\$ 6,000$, and more than $\$ 1,000$ had to be borrowed from the bishop..$^{32}$ One of the major and constant problems facing the missionaries was the lack of money. A boarding school was an expensive proposition, but the Catholic missionaries were willing to pay the price, believing that the schools were invaluable for the "civilizing" of the Indians. ${ }^{33}$ The Oblates and sisters who worked at the schools and received government salaries donated much of their wages to the missionary society to augment the funds received from the per capita grant and private donations. ${ }^{34}$ Public appeals for charity were constantly made by the Oblates. 
When the per capita grant was increased (from $\$ 72$ to $\$ 100-\$ 125$ ) as part of the 1910 government reforms to improve the calibre of teaching and the physical conditions of the boarding schools, it paid dividends. Although the Sisters of the Assumption expressed worry that they would be unable to meet the requirements of the grant, improvements to the school at Hobbema were made by August of 1911. A new ventilation system was built, as was a "hospital," where sick children could be placed to avoid the spread of disease. ${ }^{35}$ The next year, a basement was excavated to make more room, and the school's attendance rose to 75. The First World War caused cutbacks in government funding, but, after this period, the school continued to grow over the years with further government allocations. By 1929, there were 130 students. ${ }^{36}$ But, even though the missionaries relied a great deal on government money to stay in operation, they did not always like to deal with the bureaucracy of the Department of Indian Affairs, which could be slow to respond to their demands. ${ }^{37}$ Nevertheless, the symbiotic relationship between the government and the Catholic missionaries in relation to Indian education was to continue well into the 1960 s. But that is beyond the scope of this paper.

Since the goals of the boarding schools were to "civilize" the Indians, the curriculum, which was standardised by the government in 1880 , was meant to emphasize European values. By 1894, the required courses, as outlined by the Department of Indian Affairs, included English, reading, recitation, writing, arithmetic, general knowledge, geography, ethics, history, vocal music, calisthenics, and religious instruction. ${ }^{38}$ However, the department did not expend much effort in monitoring the courses that were taught in the Indian schools. Organized recreational acrivities were also seen as helping to civilize the Indian, and European sports like football were emphasized. ${ }^{39}$ At the Ermineskin school, a brass band for the boys and a mandolin orchestra for the girls were formed in 1906. The band and orchestra performed for appreciative guests, such as D.C. Scott, the Superintendent of Indian Affairs. The mandolin players also travelled to other parts of the province to give benefit concerts, and, according to the Sisters of Assumption, the players were often "enchanted" with what they saw of the wider world. ${ }^{40}$ Like most other residential schools, the Ermineskin school operated on a system where half the day was devoted to manual work. After class hours, the boys learned about farming, animal husbandry, and woodwork, while the girls learned needlework and other domestic arts. These were practical skills, for the school itself relied on its garden and cattle for food. The school report of 1900 showed a harvest of 100 bushels of poratoes and 50 bushels of assorted legumes. That year, the girls made 50 dresses, 100 aprons, 100 shirts, 


\section{Past Imperfect}

and 60 pairs of stockings. ${ }^{41}$

Although many Indians were wary of what the residential schools had to offer, more than a few were in favour of education because they believed it would benefit them to learn the white man's ways. While estimates of school attendance are hard to find, some official estimates place the attendance of Indian school-age children at 25 to 50 per cent in any given area where schooling was available. ${ }^{42}$ A 1909 memo from W.M. Graham, the Inspector of Indian Agencies, claimed that "today ... it is quite common for Indians to place their children in school of their own accord." 43 The Sisters of the Assumption also remarked in 1909 on the interest taken by parents in their children's progress: "Ils aiment à constater les progrès de leur enfants." 44

Despite discontentment with boarding and industrial schools, the Indians apparently saw that the schools might be beneficial in giving their children the education they needed to live in a white-dominated society. In fact, some schools which had a reputation for efficiency even developed long waiting lists. ${ }^{45}$ But, the apparently increasing Indian acceptance of education can also be seen as a form of acquiescence to the coercive demands of white government officials and missionaries. For instance, under the Indian Act, the government closely supervised the land, economy, politics, education, and even the personal decisions of the Indian people. ${ }^{46}$ Hence, for Indians living under such coercive and controlled conditions, compliance with the wishes of the authorities might have been the best option in certain cases.

Without doubt, the willingness of parents to send their children to school was also often due in no small part to the influence of respected priests, who actively recruited children. For example, Père Perreault's zeal and knowledge of the Cree language was credited with turning Indians, who were veering towards Protestantism, back into the folds of the Catholic church. When Perreault died in 1900, both the Sisters of the Assumption and the Hobbema Indians, who held him in high esteem, were greatly saddened. ${ }^{47}$ It is interesting to note that, however much the Oblates wanted the Indians to become civilized, they, themselves, often had to learn the native language in order to function in the community and to gain converts in a time of intense rivalry with the Protestant denominations. ${ }^{48}$ Speaking the native tongue was very important, especially in the early days of the itinerant missions, but that facility remained important well into the 1900 s.

The sense of duty and devotion that characterized the sisters and the Oblate priests should not be underemphasized, whatever their other shortcomings might have been. The Catholic missionaries chose a life of chastity, poverty, and obedience, and they dedicated themselves to their work despite the setbacks and hardships that often went with it. 
Although there was sometimes friction between individuals, there was also cooperation and self-sacrifice. Père Louis-Joseph Dauphin noted of the Sisters of the Assumption: "Les soeurs se montrent toujours bien devoués et bien courageuses. Pour moi, je ne puis cesser de les admire." 49 As is evident throughout their Chronicles and other records, the sisters tended to look at their situation with a positive, if pious, disposition. On many occasions, they also made mention of the happiness of the children in their care. Based on the forthcoming evidence in this paper, one can conclude that perhaps the sisters were more than a little prone to exaggerating that happiness. But one wonders just how much their outlook was influenced by the conviction that what they were doing was the right thing.

However, despite their sometimes self-congratulatory attitude, the missionaries encountered many problems with the boarding schools. Attendance and discipline remained problems at schools, even after the government made attendance compulsory for Indian children in 1894. As with so many other Department of Indian Affairs policies, nothing was done by officials to enforce the truancy provisions. Indians, whose values and behaviour were often at odds with the routine expected by the missionaries, actively resisted the educational efforts of the missionaries in many cases. Some idea of this is revealed in the Hobbema Chronicles of the Sisters of the Assumption. The entry dated September 1894, the first month of the boarding school's existence, noted:

Les enfants ne se font pas prier pour venir à l'école des Soeurs. Nous avons dès le commencement une bonne résistance. Les enfants sont très difficiles. Le silence pendant la classe s'observe plus ou moins bien, et la rentrée après la récréarion du midi ne se fait que difficilement. Au son de la cloche au lieu de se hâter d'entrer, les uns prennent le champ, les autres vont manger des oeufs au poulailler. ${ }^{50}$

On October 10 of that year, one of the sisters was hit with a stick by a large boy. The principal, Père Victorin Gabillon, was called and he administered several slaps to the boy, making him ask for forgiveness, and making an example of him to the other students. The boy was suspended for a week, but when he returned he became a model student. ${ }^{51}$ Often, however, such disciplinary measures were disliked by Indian parents, who did not physically punish their children. ${ }^{52}$

Indian parents were loath to enrol their children in boarding schools for several other reasons. Many parents deplored the deliberate policy of cultural transformation that took place in the schools. For instance, students were often punished for speaking their native language in the 


\section{Past Imperfect}

schools. Indians may have wanted education, but they were not prepared for their children wholly to give up their culture as the missionaries demanded. Indians were also scornful of the poor calibre of teaching and of the supposed benefits of schooling. The education the Indians received did not guarantee they would be accepted by the wider society, as most graduates were unable to find jobs in the white man's world where they were discriminated against. Sometimes, parents also questioned the true motives of the missionaries, who were funded on a per student basis. Père Louis-Joseph Dauphin, who served as principal at Hobbema from 1900 to 1914, wrote in May 1902 to Père Albert Lacombe telling him of his appreciation for the job done by the Sisters of the Assumption. But he added that the Indians did not seem to realize that: "Au contraire, ils semblent croire qu'elles sont là pour faire de l'argent." 53 The fact that residential school students were compelled to spend half of every day on menial and sometimesbackbreaking chores also angered some parents, who believed the missionaries were only interested in getting cheap labour. ${ }^{54}$

Even if Indian children were enrolled in a school, there was no guarantee they would stay. Most students who began school never finished and achieved only a low level of education. In an October 1901 letter to Lacombe, Dauphin complained that the number of students had dropped from 75 to 54 because of parents who, for one reason or another, had pulled their children out of the school. ${ }^{55}$ Often, Indians retained a semi-nomadic and hunting lifestyle, which made regular attendance impossible. Furthermore, parents who lived on reserves far from the boarding school might not see their children for long stretches of time, so it was understandable that they would be reluctant to part with their children in the first place. In fact, in the early years, the department discouraged students from visiting home because it was believed they would be exposed to "undesirable influences" there. ${ }^{56}$ Under such conditions, it is not surprising that children regularly attempted to run away from the schools.

Another of the main reasons why Indians were reluctant to send their children to boarding schools was because of health conditions. It was not uncommon for apparently perfectly healthy children to fall sick and, in many cases, to die while attending boarding schools. ${ }^{57}$ A 1907 investigation by Dr. P.H. Bryce, the chief medical officer for Indian Affairs, found that large numbers of students with infectious diseases were admitted to the schools, whose "defective" sanitary conditions provided a fertile breeding ground for the diseases. Bryce noted that poor ventilation was one of the prime factors in spreading disease, for, in most cases, dormitory windows were sealed during winter to save on heating costs. The doctor also noted that principals and teachers were 
inclined to minimize the dangers and were reticent about the fate of their former pupils. ${ }^{58}$ Some estimates claim more than one-quarter of pre-1914 students succumbed to disease during or shortly after their stay at the schools. ${ }^{59}$

The Chronicles of the Sisters of the Assumption tell of several deaths and outbreaks of sickness over the years. The sisters were concerned with the effect the deaths would have on the Indian parents, who might be prompted to remove their other children. The October 20, 1901 entry, noting the deaths of an 11-year-old girl and a 10-year-old boy from measles, also lamented:

C'est un grand coup pour nous - deux enfants en si peu de temps parce que les sauvages s'imaginent que leurs enfants ne mourraient pas s'ils n'étaient pas à l'école. Ils étaient tous deux bien préparées et contents de mourir. ${ }^{60}$

The statement about the children being well-prepared to die, while somewhat morbid, seems to indicate that the sisters thought they did their best to make the Indians good Christians. For the sisters, devorion to God was apparently a more crucial priority than the health of the children. The sisters noted several times that their grief over the deaths of students was ameliorated by the fact that those students had found God and could thus leave this earth knowing they were going to a better place. ${ }^{61}$ However, the sisters' concern over what the parents thought about the situation also reveals that tensions existed between Indians and missionaries. Two years later, three more children died of "consumption" or tuberculosis. One of them, a boy, died while reciting the catechism. According to the sisters, his death left a profound impression on the spirits of the other children. In December of that year, a fourth child got a haemorrhage and was sent home by the sisters, who explained their actions by noting that, "Comme nous n'aimons pas que le quatrième enfant meure à l'école cette année, nous lui conseillons d'aller faire une promenade dans sa famille."62

To the modern observer, the sisters may appear to be unfeeling, callous and even cruel. But, in fairness to them, living conditions for students at Hobbema were in fact better than at many other boarding schools. The sisters even noted that some of their students became attached to them due to the care they provided. ${ }^{63}$ The new ventilation system that was installed at the Hobbema school in 1911 may also have concributed to an improvement in health conditions there. In fact, during a 1920 inspection, conditions at Hobbema were reported to be satisfactory and the children were said to be clean, well-fed, and healthy. ${ }^{64}$ Moreover, boarding schools must not shoulder all the blame 
for the Indians' poor health. It should be noted that the incidence of diseases was also high on the reserves themselves, due to poor living conditions and the Indians' lack of immunity to certain diseases.

The Chronicles also tell of picnics, sleigh rides, and outings over the years, but, even 20 years after the school was established, the children did not always happily adjust to their surroundings. Boredom and homesickness, especially among those children who came from other reserves, continued to be problems. Similar problems existed among white students in public schools, especially those in rural areas. Yet, one is led to believe that the situation was worse for Indian children, for they came from a culture whose concepts were often totally incompatible with European schooling methods and they had less opportunity to resist the system that was foisted upon them. ${ }^{65}$ Père Jules Chevallier noted that in September and October of 1914, "plusieurs enfants s'enfuient de l'école à differentes reprises. Il n'y a pas très bon esprit à l'école. Neanmoins j'obtiens plusieurs nouveaux et nous restons encore à 50 enfants. ${ }^{\circ 6}$ Chevallier did not give the reasons for the discontent, but it has been noted previously in this paper that the daily routine was not always compatible with the Indian outlook. Students had to wear the white man's clothes, to eat his food (which was often of poor quality and of meagre supply in the residential schools), and to learn his education and games. Often, there was a competitive or coercive nature to these pursuits, which did not accord with traditional Indian values of communalism. ${ }^{67}$

The idea behind the education of Indians was to get rid of the old and to inculcate the new. This much was made clear by the Office of the Commissioner of Indian Affairs in numerous circulars and memos sent to the schools during the $1890 \mathrm{~s} .^{68}$ For example, children were to be registered with Christian names to avoid confusion with their Indian names. ${ }^{69}$ Although the bureaucrats usually did not bother to enforce their policies, student discharges and marriages between young people were also to be approved by the Office, which wanted the Indians to "reflect credit" on the schools. According to an 1895 letter from the Office, young women were to be trained so they would "elevate" their future husbands. Indian women were expected to learn the "domestic arts" of cooking, cleaning, and caring for a household. Before marriage, the men were to have a house, cattle, farming implements, morality, and industry. ${ }^{70}$ But, to the chagrin of the missionaries, children often reverted back to "savage" practices once they left school, due to peer pressure and parental influence. ${ }^{71}$ In 1901 or 1902, Père Dauphin wrote Père Lacombe, who was in Montreal, asking if he could get the government to "s'arrêter ces concubinages qui deviennent toujours plus fréquents chez nos sauvages." 72 Dauphin noted that young people were 
neglecting their farms and parents in order to pursue common-law relationships, and he questioned his influence in being able to control the morality of Indians. Ir was a constant struggle to make the Indians give up their traditions, but it was believed by the priests that that was the only way in which they could be civilized.

Some have argued that Catholic missionaries had advantages over their Protestant counterparts when it came to winning over the Indians because they were not as dogmatic in their efforts to attain converts. ${ }^{73}$ Yet, Oblate priests did not like the idea of such Indian practices as Sun Dances, which - although forbidden under the Indian Act of 1885 were held annually at midsummer, when Indian bands would congregate at a predetermined location to participate in activities that had both a social and sacred significance. In 1896, Père Lacombe held a three-day prayer retreat at Hobbema in an effort to prevent the Indians from holding their "superstitious" Sun Dance, but, despite providing a feast for the Indians, he apparently was not too successful..$^{74}$ Indians were determined to protect their social system by performing traditional social and religious ceremonies. But the belief that the Indians had to give up their traditions persisted among the missionaries. As a 1910 letter, ostensibly written by an Oblate source at Hobbema exclaimed: "Si nous voulons civiliser les Indiens, il faut chercher à détruire ces vieilles coutumes du Sauvage."75

However ethnocentric such atticudes may be, it is necessary to emphasize that the missionaries believed that they were doing the right thing for the Indians. Despite their failures and their frustrations with Indian education, the missionaries continued to have faith that what they were offering the Indians was better than the alternative of leaving them to their "pagan" religion and to the perils of the outside world. There was a genuine belief that the poor and destitute Indians could benefit from formal education and the Christian religion. A good example of this belief is shown by Pere Pierre Moulin, who came to Hobbema in 1903 and was principal of the boarding school there from 1914 to 1938 . While doing missionary work among Indian bands living near the Cypress Hills area in 1909, he had a chance meeting with a young woman he had once known:

Je trouve là une jeune femme qui a passé à notre école Indust. de Dunbow. Depuis longtemps elle s'est négligée ... son enfant est malade. Je lui rappelle l'école - les Soeurs - et peu à peu, ayant gagné sa confiance, elle me promet de récommencer à faire ses devoirs. Et elle commença le suite. Pauvres enfants . . . toutes les occasions les guettent ... ; ils sont si faibles et ils iraient 
si rarement le prêtre - est-ce étonnant qu'ils tombent? N'est-ce pas plutôt admirable le voir comment ils sont prêts à revenir; à éssayer de faire mieux. ${ }^{76}$

Although Moulin appeared to have the best interests of the Indian people at heart, the young woman he spoke of was symbolic of the many Indians who were not able, or who were unwilling, to adapt to the oppressive regime of industrial or boarding schools. Even those few who graduated were often poorly equipped to find jobs in the white man's world, where they were discriminated against. ${ }^{77}$ The skills and trades learned at industrial schools were often useless in what was a predominantly agrarian society, and Indians often had no place to go but back to the reserve where they would remain unemployed and in need of government welfare. ${ }^{78}$ The Indian agent for Hobbema, D.L. Clink, publicly voiced his displeasure with the residential and industrial school system in an 1896 letter to the editor of the magazine, Progress. Contrary to department policy not to voice criticisms publicly, Clink complained that graduates did not have enough practical training and were less able to be mixed farmers than young men who had never left the reserve. ${ }^{79}$

A large part of the blame for this situation might be attributed to the agricultural policies of the Department of Indian Affairs. During the treaty-making process, Indians made it clear they wanted to establish agriculture on the reserves as they needed a permanent means of sustenance. The government's publicly-stated aim was to assist Indians to adopt agriculture. The main way of doing this was by providing instructors to teach the Indians how to farm. But, all too often, Indian Affairs supplied instructors unfamiliar with western conditions, neglected to provide good implements and seed in time, and became impatient when Indians showed slow progress. Compounding the problem were the poor climatic conditions that existed in the late $1880 \mathrm{~s}$ when the agricultural program was beginning. Furthermore, the government took away Indian initiative to farm by discouraging large-scale communal farming. Beginning in the late 1880 s, the government pushed for the subdivision of reserve lands into individual holdings. The Indians resisted this "allotment in severalty" as they recognized it was an attempt to extinguish their Indian identity and the reserves. It is also quite apparent that Ottawa - possibly fearing a backlash from white settlers upset with the subsidization of Indian agriculture wanted the Indians to become subsistence peasants, who would farm with hoe and scythe. For example, the government introduced a system whereby permits were required for the sale of produce from the reserve. It was easy for officials to reject Indian requests for permits. Thus, Indians were unable to sell their produce to buy labour-saving machin- 
ery that would help them to compete against their white neighbours in an export-driven economy. The administrative policies that promored "allotment in severalty" and "peasant" farming did much to limit Indian initiacive and agricultural productivity. Yet, after 1896, Indian Affairs also surrendered much reserve land that was suitable for farming to white homesteaders, rationalizing that they would make better use of it than did the lndians. ${ }^{80}$

In conclusion, as we have seen, the government and the missionaries became interdependent during the process of educating and "civilizing" the Indians of the Northwest. Oblate missionaries had been providing rudimentary education to the Indians since the 1850 s. However, in the 1870s, the Dominion government, which had treaty obligations to provide education, developed a policy of funding missionary-run Indian schools. Both the government and the missionaries saw the lndians as needing outside intervention to help them cope with the threats of starvation, disease and white settlement. They also had other selfish motivations, which often seemed to take precedence over their concern for the Indians. The missionaries wanted converts, while the government wanted to settle the prairies cheaply and peacefully. Both parties saw education as being important in achieving these goals, and in helping the Indians to acculturate to Canadian society. The fact that the missionaries and the government saw the culture of the prairie Indians as being uncivilized and unprogressive led them to treat the Indians in an extremely paternalistic and ethnocentric way. They had no intention of preserving Indian culture; rather, they determined that the Indians should adopt the values of the dominant white society. Yet, in the long run, the assimilationist hopes of the missionaries and the government were to be dashed. The reserve system, which was intended to prepare Indians for eventual assimilation, had the opposite effect. Isolated from white society on their reserves, Indians were able to keep their sense of identity and to persist in their own cultural traditions.

The Hobbema records of the Oblates and the Sisters of the Assumption show us that Indians often resisted missionary efforts at education. These findings are quice similar to those which appear in the existing literature. At Hobbema, parents would remove their children from the schools or not enrol them at all. Parents questioned the motives of the missionaries, the health conditions at the schools, and the benefits of the education. Children were made to conform, often forcibly, to the ways of the white man. Some children were obviously not happy, and suffered from boredom and homesickness, although it must be said that the boarding school experience had its enjoyable moments. The mandolin players at Hobbema got a chance to travel to other parts of the province, for example. Indeed, to a degree, the situation for the students 


\section{Past Imperfect.}

at Hobbema was probably not as bad as it was for some Indian students elsewhere. However, in almost all instances, the education that Indians received was of poor quality and did not guarantee they would be accepted into the wider society. Most students dropped out after a few years and those who did graduate were unable, or were not given the chance, to mix with white society as equals. There was usually no place for them to go but back to the reserves, where many reverted to their "heathen" practices despite their schooling and the efforts of the missionaries. In most cases, they also needed government relief. The schools must shoulder part of the blame for this state of affairs, but government regulations which circumscribed the initiative of the Indians to support themselves by farming also contributed to the marginalization of Indians.

Nevertheless, some Indians believed education could be valuable in helping them to deal with the dominant society, so they continued sending their children to school where they could learn the white man's knowledge. The practice of parents enrolling their children in school was often due to coercion, but it can also be partly attributed to the influence of the Oblate priests, who could command great respect among the Indians. The Oblates and the Sisters of the Assumption were a dedicated lot, and they genuinely believed that what they were doing was best for the Indians. They believed in their God-given duty to "civilize" the Indians, yet — in the process of saving souls - they tended to overlook their failures which were many and profound. To be sure, some Indians were taught certain practical skills and how to read and write in English, but at what price? For one thing, many lost their lives at the residential schools. For another, the education system was structured so that children were explicitly and implicitly taught that to be an Indian was to be inferior. Many Indians who had had their language and culture stripped from them by missionary schooling also ended up living an anomic existence on the fringes of the white and Indian worlds once they left school. It is not difficult to conclude that the self-image and psychological well-being of the Indian would be affected in these circumstances. While it could be argued that the Indians might have suffered a worse fate were the missionaries not there to help them adapt to the exigencies of a new society, the legacy of the residential schools is a sorry one. 


\section{NOTES}

'See, for example, Jacqueline Gresko, "White 'Rites' and Indian 'Rites': Indian Education and Native Responses in the West, 1870 - 1910," in Western Canada Past and Present, ed. Anthony W. Rasporich (Calgary, 1975). Gresko's work is on the Qu'Appelle Industrial School. To my knowledge, boarding schools as such have not been systematically examined and the historical record on them is yet to be fully established.

${ }^{2}$ Edmonton Journal, 25 July 1991

${ }^{3}$ Harold Cardinal, The Unjust Society: The Tragedy of Canada's Indians (Edmonton, 1969)

${ }^{4}$ Jacqueline Gresko, "Creating Little Dominions within the Dominion: Early Cacholic Indian Schools in Saskatchewan and British Columbia," in Indian Education in Canada: The Legacy, eds. Jean Barman, et al. (Vancouver, 1986), 88 'John Webster Grant, Moon of Wintertime: Missionaries and the Indians of Canada in Encounter since 1534 (Toronto, 1984)

${ }^{6}$ Brian M. Owens and Claude M. Roberto, A Guide to the Archives of the Oblates of Mary Immaculate: Province of Alberta-Saskatchewan (Edmonton, 1989), 1

${ }^{7}$ J. Brian Dawson, "The Relationship of the Catholic Clergy to Metis Sociery in the Canadian North-West, to 1845 - 1885; With Particular Reference to the South Saskatchewan District" (Ottawa: Parks Canada Manuscript Report no. 376, 1979) 8, 101, 118

${ }^{8}$ Gerald Arthur Falk, "Missionary Education Work Amongst the Prairie Indians, 1870 - 1914" (MA thesis, University of Western Ontario, 1973), 1

'Provincial Archives of Alberta (PAA), Papiers des Soeurs de l'Assomprion de la Ste. Vierge (SASV), 73.489/15/9, "Programs Feb. 1901 - Dec. 1967," 28 June 1915. The material is labelled according to a two-numeral system devised by the SASV. Thus, the first numeral in SASV $15 / 9$ refers to the house or convent concerned, " in this case, Hobbema; while the second numeral signifres the category to which the document belongs.

${ }^{10}$ Marion Joan Boswell, "'Civilizing' the Indian: Government Administration of Indians, 1876 - 1896" (Ph.D. thesis, University of Ottawa, 1977), 226

"Treary No. 6 Between Her Majesty The Queen and the Plain and Wood Cree Indians and Other Tribes of Indians at Fort Carlton, Fort Pitt and Battle River with Adhesions

${ }^{12}$ Alexander Morris, The Treaties of Canada with the Indians of Manitoba and the North-West Territories, including the negotiations on which they were based, and other information relating thereto (1880; reprint, Toronto, 1971)

${ }^{13}$ Falk, "Missionary Education Work," 20

${ }^{14}$ E. Brian Titley, A Narrow Vision: Duncan Campbell Scott and the Administration of Indian Affairs in Canada (Vancouver, 1986), 75-76

${ }^{15}$ Gerald Friesen, The Canadian Prairies: $A$ History (Toronto and London, 1987), 160

${ }^{16} \mathrm{Grant}$, Moon of Wintertime, 183-85

${ }^{17}$ Jean Barman, Yvonne Hebert, and Don McCaskill, eds., Indian Education in Canada: The Legacy (Vancouver, 1986), 3 
${ }^{18}$ Ibid., 5

${ }^{19}$ James Rodger Miller, Skyscrapers Hide the Heavens: A History of Indian-White Relations in Canada (Toronto, 1989), 83-84

${ }^{20}$ Falk, "Missionary Education Work," 14

${ }^{21}$ Titley, Narrow Vision, 76-77

${ }^{22}$ Falk, "Missionary Education Work," 183

${ }^{23}$ Ibid., $183-86$

${ }^{24}$ PAA, Oblates of Mary Immaculate Papers (OMI), 84.400/974, Bishop Grandin to Madame, 17 Jan. 1878

${ }^{25}$ The French term "sauvages" or "savages" was used by missionaries to describe a culturally deprived group. While pejorative, it should not be confused with the modern derogatory sense of the term.

${ }^{26}$ P.E. Breton, Hobbema: une florissante mission indienne de l'Ouest (Edmonton, 1962), 22-23. Breton was a member of the OMI order.

${ }^{27} \mathrm{OMI}, 71.220 / 3849$, "L'histoire de l'école et de la mission d'Hobbema depuis 1841 à 1955," by Henri Guibert, circa 1955

${ }^{28}$ The Department of Indian Affairs wished to avoid denominational conflict in the establishment of schools, and so had certain guidelines for funding (OMI, 71.220/9076, Department of Indian Affairs Assistant Commissioner Hayter Reed to Père Alberta Lacombe, 3 Dec. 1887):

The suggested rule is, that after one school for any Reserve has been authorized by this Office, with a teacher who is of the same denomination as the majority of the Band -- whether appointed by this Department or by a religious body -- no other school shall be given any grant or assistance of any nature unless it obtain an average daily attendance of at least eight pupils.

${ }^{29} \mathrm{OMI}, 71.220 / 3849$, "L'histoire de l'école et de la mission," by Guibert

${ }^{30}$ In addition to the Ermineskin band, there was the Bobtail or Montana band and the Samson band. The Bull band was formed later. Each band had its own reserve in the Hobbema area. The Ermineskin and Bobtail bands were predominantly Catholic (Breton, Hobbema, 11).

${ }^{31} \mathrm{OMI}, 71.220 / 3998$, "École Hobbema -- Historique de l'école résidentielle 1970." The author is unknown.

${ }^{32}$ OMI, 71.220/3849, "Quelque extraits de: Registre pour servir à l'inscription des Chroniques des Soeurs de l'Assomption de la Ste. Vierge -- Hobbema," by P.E. Breton, 1 Aug. 1961

${ }^{33}$ Falk, "Missionary Education Work," 196

${ }^{34}$ Ibid., 193

${ }^{35}$ SASV, 73.489/15/1a, "Chroniques, 1894 - 1936," 2 Aug. 1911. The "Chroniques" consist of journal entries written by the Sisters of the Assumption.

${ }^{36}$ Breton, Hobbema, 36

${ }^{37} \mathrm{OMI}, 71.220 / 9076$, letter to missionaries and religious communities from Emile J. Legal, Bishop of St. Albert, 11 June 1911

${ }^{38}$ Boswell, "Civilizing' the Indian," 256 
39) Ibid., 305-06

${ }^{40}$ SASV, 73.489/15/1a, "Chroniques," 19 Dec. 1906, 9 Aug. 1910, 17 Oct. 1911

${ }^{41}$ Breton, Hobbema, 25-26

${ }^{42}$ Gresko, "White 'Rites' and Indian 'Rites'," 174

${ }^{43} \mathrm{OMI}, 71.220 / 9075$, memo from W.M. Graham, Inspector of Indian Agencies, 1909. This is excerpted from a 1909 Department of Indian Affairs report.

${ }^{44}$ [They like to notice the progress of their children.] SASV, 73.489/15/1a, "Chroniques," 11 Feb. 1909

${ }^{45}$ Grant, Moon of Wintertime, 183

${ }^{46}$ Friesen, Canadian Prairies, 157

17 SASV, 73.489/15/1a, "Chroniques," 17 Oct. 1900

${ }^{48}$ At Hobbema, there was a strong Methodist presence that was concentrated in the Samson band. Figures given by Frère Henri Guibert showed that in 1906, of the 681 Indians on the reserve, 323 were Methodists, 313 were Catholics, and 45 were pagans (OMI, 71.220/3849, "L'histoire de l'école et de la mission"). But there were numerous conversions to Catholicism in 1918 when 90 of the 850 Indians on the reserve died of "Spanish flu." Breton claims that no true Catholic died from the influenza and cites the survivial of all 57 students and 10 "religieuses" at the boarding school (Breton, Hobbema, 35).

49 [The sisters always appear devoted and courageous. I cannot stop admiring them.] OMI, 71 .220/7946, Père Louis-Joseph Dauphin to Père Albert Lacombe, 10 Oct. 1901

so [The children willingly come to the school. (Yet) there has been considerable opposition from the beginning. The children are very difficult. They maintain a wary silence during class, and their return to class after the noon-hour break is done with nothing but difficulty. At the sound of the bell, instead of hastening to enter, some run off, while others go to eat the eggs in the henhouse.] SASV, 73.489/15/11a, "Chroniques," Sept. 1894

s1 Ibid., 10 Oct. 1894

52 Boswell, "Civilizing' the Indian," 301

${ }^{53}$ [On the contrary, the Indians appear to believe that the sisters are there to make money.] OMI, 71.220/7946, Dauphin to Lacombe, 20 May 1902

${ }^{54}$ Gresko, "White 'Rires' and Indian 'Rites'," 174

ss OMI, 71.220/7946, Dauphin to Lacombe, 10 Oct. 1901

${ }^{56}$ Tirley, Narrow Vision, 78

57 Boswell, "Civilizing' the Indian," 294

${ }^{58}$ Titley, Narrow Vision 84

${ }^{39}$ Miller, Skyscrapers Hide the Heavens, 199

${ }^{60}$ [It is a big blow for us to have two children die in so little time because the Indians think that if their children were not at the school, they would nor die. They were boch well-prepared and content to die.] SASV, 73.489/15/1a, "Chroniques," 20 Oct. 1901

${ }^{61}$ Ibid., 26 Oct. 1903, 11 Dec. 1905

${ }^{62}$ [As we did not like a fourth child to die at the school this year, we advised him 
to go back to his family.] Ibid., 6 Dec. 1903

${ }^{63}$ Ibid., 21 Nov. 1911

${ }^{64}$ Titley, Narrow Vision, 88

${ }^{65}$ Grant, Moon of Wintertime, 189

${ }^{66}$ [several children ran away from the school at different times. There is not a good spirit at the school. Nevertheless, I obtained several new students and the number remains at 50.] OMI, 71.220/3802, "Hobbema -- Notes trouvées dans les papiers du père Jules Chevallier 1895 - 1915," Sept. and Oct. 1914

${ }^{67}$ Boswell, "Civilizing' the Indian," 298-305

${ }^{68}$ The Office of the Commissioner of Indian Affairs was created when the Conservatives came back to power in 1878. Prime Minister John A. Macdonald, as Minister of the Interior and Superintendent General of Indian Affairs, sent Edgar Dewdney west as Indian Commissioner in an attempt to reorganize the Indian Service of the North-West Territories and to ensure that treaty provisions were carried out.

${ }^{69}$ OMI, 71.220/9076, circular from Office of Indian Commissioner to principal of Lac La Biche boarding school, 7 Oct. 1896

${ }^{70}$ Ibid., letter from Office of Indian Commissioner to principal of Lac La Biche boarding school, 17 Jan. 1895

${ }^{71}$ Gresko, "White 'Rites' and Indian 'Rites'," 176

72 [stop these concubinages which are becoming more frequent among our Indians.] OMI, 71.220/7946, Dauphin to Lacombe. This particular letter is undated, but it is among a group of letters written during 1901 and 1902 to Lacombe in Montreal.

${ }^{73}$ Falk, "Missionary Education Work," 200

${ }^{74} \mathrm{OMI}, 71.220 / 3802$, "Hobbema -- Notes trouvées dan les papiers du père Jules Chevallier," 13 June 1897

${ }^{75}$ [If we want to civilize the Indians, it is necessary to destroy their old customs.] OMI, 71.220/3859, "École Hobbema -- Dossier de correspondance officielle 1910." Part of this 3 Aug. 1910 letter is lost, and it has no signature.

${ }^{76}$ [I found a young woman there who had once attended our industrial school at Dunbow (High River). For a long time she had neglected herself. . . her child was sick. I reminded her of the school and the sisters and, little by little, having won her confidence, she promised me to return to her duties. And she began to do what she had promised. Poor children . . . every circumstance lies in wait to take advantage of them ... ; they are so weak and they go so rarely to the priest - is it surprising that they fall? Is it not rather admirable to see how they consent to return, to try to do their best.] OMI, 71.220/7014, "Souvenirs de ses temps à Hobbema -- 1906," by Pierre Moulin. It is unclear as to when this passage was written, but it can be dated to sometime in the spring of 1909 .

${ }^{77}$ Boswell, "'Civilizing' the Indian," 315

${ }^{78}$ Falk, "Missionary Education Work," 66

${ }^{79}$ OMI, 71.220/3991, D.L. Clink to the Editor of Progress, 1 March 1896

${ }^{80}$ Miller, Skyscrapers Hide the Heavens, 199-202 